возрастных групп животных.

Зараженность лошадей гельминтами зависит от многих факторов. На одной конюшне и в одном табуне лошади могут быть заражены различными видами гельминтов с разной интенсивностью инвазии (заражения паразитами). Предрасполагающими факторами для развития заболевания лошадей гельминтами являются: наследственная предрасположенность, условия содержания, тип кормления, степень эксплуатации, какие лекарства получало животное в течение жизни (особенно антибиотики и гормоны).

Список литературы:

1. Ливанова, Т.К. Лошади: учебник / Т.К Ливанова. - М.: Астрель, 2004. $256 \mathrm{c}$.

2. Макбейн, Сьюзан. Породы лошадей. Иллюстрированная энциклопедия /С. Макбейн. - М.: Астрель,2006. - 256с.

3. Смирнов, Л.А. Лошади (Конские породы): учебное пособие /Л.А. Смирнов, И.В Мердер. - М.: Астрель,2007. - 224с.

4. Красников, А.С. Практикум по коневодству: учебное пособие /А.С. Красников. - М.: Колос, 1977. - 159с.

5. Козлов, С.А. Коневодство: учебное пособие / С.А. Козлов, С.А. Зиновьева, Н.Ю. Козлова. - СПБ: Издательство «Лань», 2005. - 128c.

6. Калашников, В.В. Практическое коневодство: учебник /В.В. Калашников., Ю.А. Соколов., В.Ф. Пустовой; под ред. Калашникова В.В. и Пустового В.Ф. - М.: Колос, 2000. - 376 с.

7. Лазовский, А.А. Породы лошадей: справочник/А.А Лазовский. Витебск , 2003. - 89c.

Научный руководитель: д.б.н., проф., член-корр.НАН Б Гончаренко Г.Г.

Статья отправлена: 05.06.2017 г.

(C) Гаврилова Е.В.

\title{
ЦИТ: иа117-035
}

DOI: 10.21893/2415-7538.2016-06-5-035

Вайбала І.О, Чушенко В.М., Ковальов В.В
РОЗРОБКА СКЛАДУ ЕКСТЕМПОРАЛЬНОЇ МАЗІ ДЛЯ ЛКУАННЯ ПСОРІАЗУ

Національний фармацевтичний університет. Харків.

I.O. Baybala, V.M. Chushenko, V.V. Kovalev

DEVELOPMENT OF THE EXTEMPORAL OINTMENT COMPOSITION FOR THE PSORIASIS TREATMENT

Анотаџия. У роботі розглядається створення екстемпоральної мазі для лікування псоріазу.

We consider the creation extemporal ointment for the psoriasis treatment

Ключеві слова: псоріаз, мазь, psoriasis, ointments, extemporaneous

Вступ

Поміж актуальних проблем сучасної дерматології псоріаз є одним із 
найбільш поширених дерматозів. Псоріаз і в даний час як хронічний дерматоз, $\epsilon$ одним 3 тих захворювань, що реєструються найчастіше. Ця хвороба залишається однією 3 найактуальніших проблем наукової $\mathrm{i}$ практичної дерматології. Зараз безліч науково-дослідницьких інститутів, учбових закладів , лабораторії займаються дослідженням походження, проявів, розробкою нових методів лікування та профілактики псоріазу. У нашій країні вивченням проблем псоріазу займався Центральний науково-дослідницький інститут. За кордоном основним науковим центром є Стенфордський університет в США, що поєднує 35 країн світу у вигляді Міжнародної асоціації по вивченню псоріазу та видавничий єдиний у світі Американський журнал псоріазу. Питаннями цієї хвороби у нашій країні та за межами плідно займаються вчені. Щорічно збільшується кількість хворих тяжкими формами дерматозу, що нерідко призводять до інвалідності (псоріатичний артрит, псоріатична еритродермія , ексудативний та пустульозний псоріаз).

За даними Міжнародної Федерації асоціацій псоріазу, його поширеність у світі коливається в межах 1,2-5 \% в загальних популяціях, становлячи в середньому близько 3 \%. У західноєвропейських країнах захворюваність на псоріаз становить більш ніж $2 \%$, в інших країнах Свропи - не перевищує $6 \%$ (в Ірландії - 5,5 \%, Іспанії - 3,7 \%, Швеції - 2,3 \%, США та Канаді ці показники $2,2 \%-4,7 \%$ відповідно). Простий (вульгарний), або бляшковий псоріаз $\epsilon$ найбільш поширеною формою захворювання, яка реєструється у 80-90\% пацієнтів. В Україні статистичні дані щодо захворюваності на псоріаз суттєво відрізняються від середніх показників в Свропі і світі, оскільки поширеність хвороби протягом останніх десятиліть неухильно зросла - від 114,8 на 100 тис. населення в 1994 р. до 222,5 на 100 тис. в 2014 р., серед яких було понад 6000 дітей. Це може бути обумовлено як недосконалістю медико-статистичних систем, так і гіподіагностикою псоріазу внаслідок низького рівня звернень пацієнтів.

Метою нашого дослідження є аналіз асортименту лікарських засобів для лікування псоріазу та вибір активних фармацевтичних інгредієнтів (АФІ), які найчастіше призначаються лікарями, і які володіють високою фармакологічною активністю. На сьогодні доведена етіологія відсутня, є лише припущення, тому, незважаючи на дотримання протоколів із доказовою базою, не завжди можна досягти бажаного ефекту у лікуванні псоріазу.

\section{Основний текст}

За останні 5-10 років у багатьох медичних дисциплінах стали застосовуватися нові терапевтичні концептуальні підходи - строго направлене цільове лікування, як можна раніше втручання і формулювання досяжних конечних цілей лікування. Причини виникнення даного захворювання до кінця не виявлені. Можливо, роль в патогенезі хвороби грають аномальні утворення кератину, епідермальна проліферація, активація імунної системи і спадкові фактори. Підвищена частота випадків псоріазу може спостерігатися серед членів однієї сім'ї: якщо псоріазом хворіють обоє батьків - ризик прояву у дитини $41 \%$, якщо один із батьків $14 \%$, якщо брат чи сестра - $6 \%$.

Приблизно четверть людей, що страждають псоріазом ураження шкіри 
були спровоковані ऑii ушкодженням, сонячними опіками або шкірними захворюваннями. Одним із факторів може стати психогенний стрес. При цьому перші прояви або загострення хвороби можуть проявлятися через декілька тижнів або місяців. У $45 \%$ випадків початок хвороби чи загострення провокується бактеріальними інфекціями. Найпоширенішим фактором $\epsilon$ фарингіт, зубні абсцеси та інфекції шкіри. Інфікування ВІЛ-інфекцією також може привести до загострення псоріазу. У ВІЛ-інфікованих псоріаз більш стійкий до лікування та часто ускладняються артритом. Відомо, що псоріаз може бути спровокований прийомом ряду лікарських препаратів : солей літію, інтерферону, -адреноблокаторів та протималярійних речовин.

Нещодавно група експертів із 19 країн Європи запропонувала включити в оновлення рекомендацій по лікуванню псоріазу три головних принципи успішної цілеспрямованої терапії, що включають строге дотримання терапевтичних алгоритмів, регулярне фіксування терапевтичної відповіді та своєчасну модифікацію лікування, якщо терапевтичні цілі не досягнені. Як відомо, принциповий вибір об'єму терапії хворого псоріазом залежить від тяжкості проявів захворювання - при тяжкому псоріазі проводять системну терапію, для легких та середніх форм можна обмежитися місцевими терапевтичними засобами, тому одним із способів вирішення проблеми $\epsilon$ можливість створення комбінованої мазі, що буде використовуватись у ціленаправленій терапії. Розглядаючи асортимент лікарськиз засобів, що призначають лікарі в Україні, можно виявити тенденцію застосування твердих, м'яких та парентеральних лікарських форм.

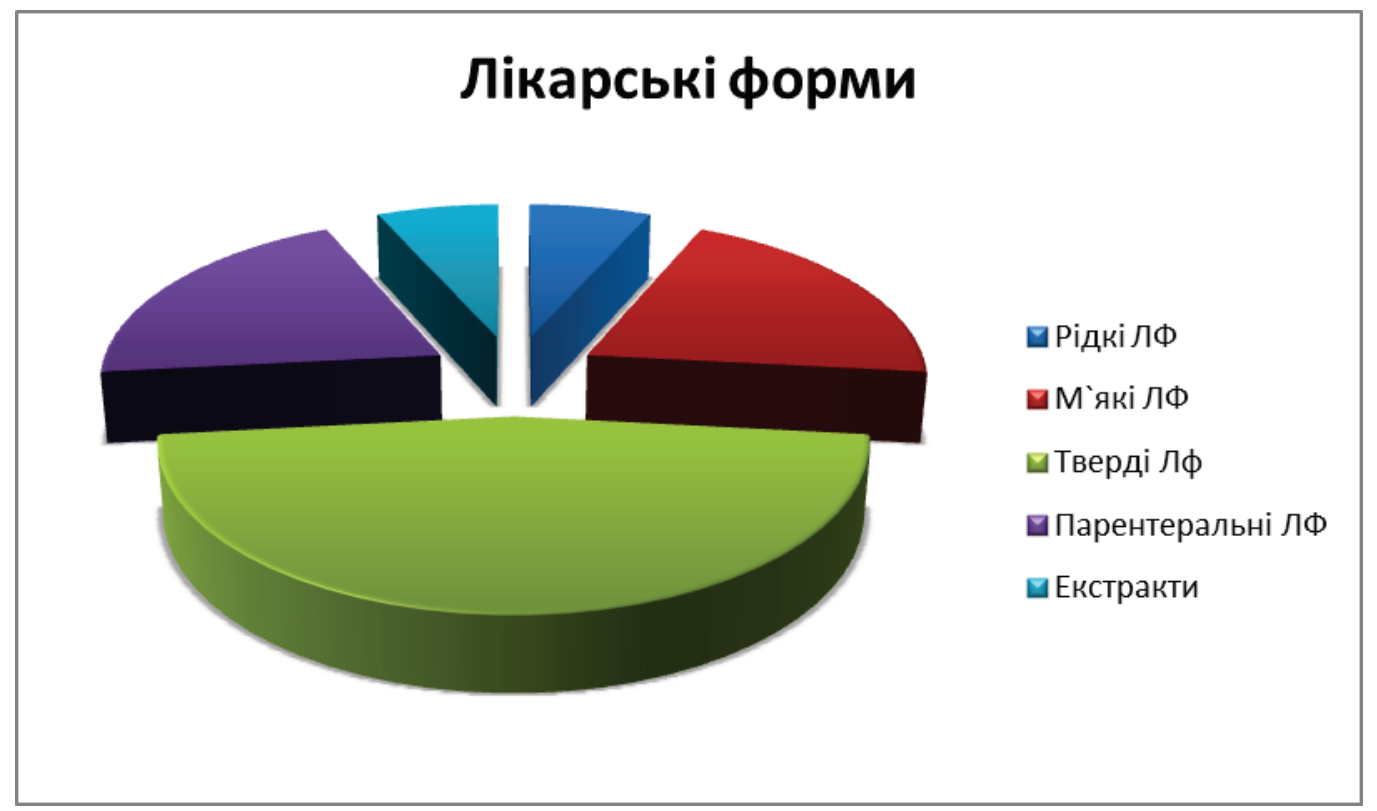

Рис. 1. Асортимент лікарських форм для лікування псоріазу (станом на 2017 p).

За даними уніфікованого протоколу медичної допомоги при псоріазі зазвичай лікування починають із місцевої терапії - застосування мазей, кремів, ліпокремів, гелей, лініментів тощо. Після бесіди із лікарями-фітотерапевтами встановлено, що перевага надається препаратам рослинного походження у 
вигляді мазей та гелей. Для лікування необхідно обрати емульсійну або гідрофільну основу, а серед активних фармацевтичних інгредієнтів (АФI) нашу увагу привернули екстракти рослинного походження, що володіють антисептичною, протизапальною, регенеративною діями та підсилюють процеси ороговіння.

\section{Висновки}

Були розглянуті причини виникнення псоріазу, тенценції терапії та визначений асортимент лікарських форм для лікування даного виду дерматозу. На основі цих даних можна зробити висновок про необхідність розробки комбінованої екстемпоральної мазі. Розглянувши вже існуючі м'які лікарські форми, треба зазначити, що мазь розроблятиметься на емульсійній основі , активні фармацевтичні інгредієнти матимуть як природнє, так і синтетичне походження для створення більш високого фармакотерапевтичного ефекту.

\section{Література}

1. Love T. J, Qureshi A. A., Karlson E. W. et al. Prevalence of the metabolic syndrome in psoriasis: results from the national health and nutrition examination survey, 2003-2006 // Arch Dermatol. 2011, Apr; 147 (4): 419-424

2. Mrowietz U, Kragballe K, Nast A., Reich K. Strategies for improving the quality of care in psoriasis with the use of treatment goals-a report on an implementation meeting // J Eur Acad Dermatol Venereol. 2011, May; 25, Suppl 3: $1-13$

3. А.К. Тимонин. Ботаника. Высшие растения (Том 3) Издательство: Академия Год: 2007- С.256; Кочетков Н.К. // Химия природных соединений. 2008. - C. 225

4. Reich K., Langley R. G., Lebwohl M. et al. Cardiovascular safety of ustekinumab in patients with moderate to severe psoriasis: results of integrated analyses of data from phase II and III clinical studies//Br J Dermatol. 2011, Apr; 164 (4): $862-872$

\section{ЦИТ: иа117-060}

DOI: $10.21893 / 2415-7538.2016-06-5-060$

УДК 615.014.2:615.451

СУЧАСНА ЕКСТЕМПОРАЛЬНА РЕЦЕПТУРА СУСПЕНЗІЙ ДЛЯ ЛІКУВАННЯ ДЕРМАТИТІВ.

Нацуінальний фармацуевтичний університет

Харків, Пушкінська, 53, 61000

Ponomarenko A.V.

MODERN EXTEMPORANEOUS COMPOUNDING SUSPENSIONS FOR THE TREATMENT OF DERMATITIS.

National pharmaceutical university

Kharkov, Pushkinskaya 53, 61000

Анотація: В роботі розглянуто дані літератури щзодо застосування 